\title{
ХАРАКТЕРИСТИКА ФАКТОРІВ ТА РИЗИКІВ ІНСТИТУЦІЙНОГО ЗАБЕЗПЕЧЕННЯ ЕКОНОМІЧНОЇ БЕЗПЕКИ АГРАРНОГО СЕКТОРУ
}

\author{
Кушнір Світлана Олександрівна \\ кандидат економічних наук, доцент \\ Запорізький національний університет (м.Запоріжжя, Україна) \\ ORCID: 0000-0002-1410-1887 \\ 2606147@ukr.net
}

У статmі розелянуто основні чинники негативної дії та ризиків інституційного забезпечення економічної безпеки аграрного сектор, до яких можна віднести сукупність умов і фракторів, а також збіг обставин, що значно збільшують ризики життєдіяльності суб'єкта бізнесу. Для формування ефективної політики щодо забезпечення економічної безпеки аграрного сектору необхідним $€$ виявлення та чітке окреслення основних її загроз та побудови їх системної класифікації Пропонується виділяти класифікаційні ознаки загроз економічній безпеці аграрного сектору із врахуванням галузевих особливостей, розроблено багатокритеріальну класифікацію загроз економічної безпеки аграрного сектору.

Ключові слова: безпека; національна безпека; економічна безпека; науковий пібхід; економічна безпека аграрного сектору.

DOI: https://doi.org/10.32845/bsnau.2019.1.10

Постановка проблеми. Основні чинники, які формують рівень економічної безпеки підприємства, різноманітні і у кожній галузі виробництва мають свою специфіку. Розглядаючи аграрний сектор, як самостійний елемент забезпечення загальної економічної безпеки країни, слід відзначити, що його діяльність носить ризиковий характер. В аграрному секторі ризик виникає на всіх стадіях господарського процесу: посів та догляд за культурами, збирання врожаю, транспортування, робота технічних засобів, залучення інвестицій, інфраструктура ринку, найм сезонних працівників та інше. Слід відзначити, що сільське господарство, на відміну від інших галузей національного господарства, має специфічну причину появи невизначеності - природні чинники, від яких залежать кінцеві результати господарювання. Тому для досягнення бажаного рівня економічної безпеки в галузі необхідно враховувати весь спектр фракторів, від яких залежить ефективність функціонування агарного сектору в умовах жорсткої конкуренції [6].

Аналіз останніх досліджень і публікацій. Проблеми економічної безпеки та економічні межі цієї комплексної дефініції в аграрній сфері досліджують М. Й. Малік, І. Ю. Гришова, А. О. Кравчук, О. О. Давидюк, О. М. Галицький, І.А.Маркіна,О.П. Дяченко, Ю.І. Данько,Я. А. Жаліло, М. В. Дубина[1-5; 8-16]. У роботах цих науковців вагома увага приділяється питанням пізнання особливостей забезпечення такого стану цього виду безпеки, який би дозволив сформувати міцну основу стійкого економічного розвитку об'єктів, у контексті яких і досліджується економічна безпека. Вагому увагу також приділено особливостям забезпечення цього виду безпеки й в аграрній галузі.

Виділення недосліджених частин загальної проблеми. Недостатньо вивченими залишаються питання виокремлення базових рівнів економічної безпеки в аграрній сффері, особливостей фуункціонування її як окремої системи взаємопов'язаних елементів, яка формується та розвивається під тиском низки чинників різної природи у стохастичному економічному середовищі.

Мета статті. Розглянемо характеристику факторів та ризиків інституційного забезпечення економічної безпеки аграрного сектору у напрямку розробки методологічної основи

\section{для наступних досліджень у цій сфері}

Виклад основного матеріалу В сучасних умовах можна виділити такі основні загрози економічній безпеці аграрного сектору, як внутрішні чинники, які підпадають під контроль підприємств галузі. До них належать обсяг фінансових ресурсів, наявність кваліфікованого персоналу, матеріальнотехнічне забезпечення, налагодження технологічного процесу, якість та структура природних ресурсів, інфоормаційноаналітичне забезпечення, робота з винахідництва та раціоналізаторства, організація системи управління та контролю, соціальний захист працівників, інвестиційний клімат на підприємстві, рівень екологізації сільськогосподарського виробництва та інтегрованість підприємства у виробничі та ринкові відносини. Основні складові економічної безпеки аграрного сектору економіки наведено на (рис. 1).

До основних складових економічної безпеки аграрного сектору можна віднести:

Фінансова складова, яка вважається основною й вирішальною, оскільки за ринкових умов господарювання фінанси $є$ «двигуном» будь-якої економічної системи.

Інтелектуальна й кадрова складова, яка забезпечує належний рівень економічної безпеки через формування складу кадрів, їхнього інтелекту та професіоналізму. Охорона інтелектуальної та кадрової складових економічної безпеки охоплює взаємопов'язані і водночас самостійні напрями діяльності того чи того суб'єкта господарюванняІнвестиційна складова, яка розглядається як елемент, що характеризується таким рівнем інвестицій, при якому аграрний сектор має можливість стало розвиватися, збільшувати виробництво, виконувати реструктуризацію та оновлювати технологічне оснащення на підприємствах галузі.

Техніко-технологічна складова, яка розглядається як процес оптимізації техніко-технологічної складової економічної безпеки, який передбачає здійснення кількох, послідовних станів.

Політико-правова складова, яка передбачає загальний процес здійснення політико-правової складової економічної безпеки, та здійснюється за типовою схемою, яка охоплює такі елементи:організаційно-економічної направленості 
(аналіз загроз негативних впливів; оцінка поточного рівня економічного забезпечення; планування комплексу заходів, спрямованих на підвищення цього рівня; здійснення планування ресурсного забезпечення; планування роботи відповідних функціональних підрозділів; оперативна реалізація запропонованого комплексу заходів щодо організації належного рівня безпеки

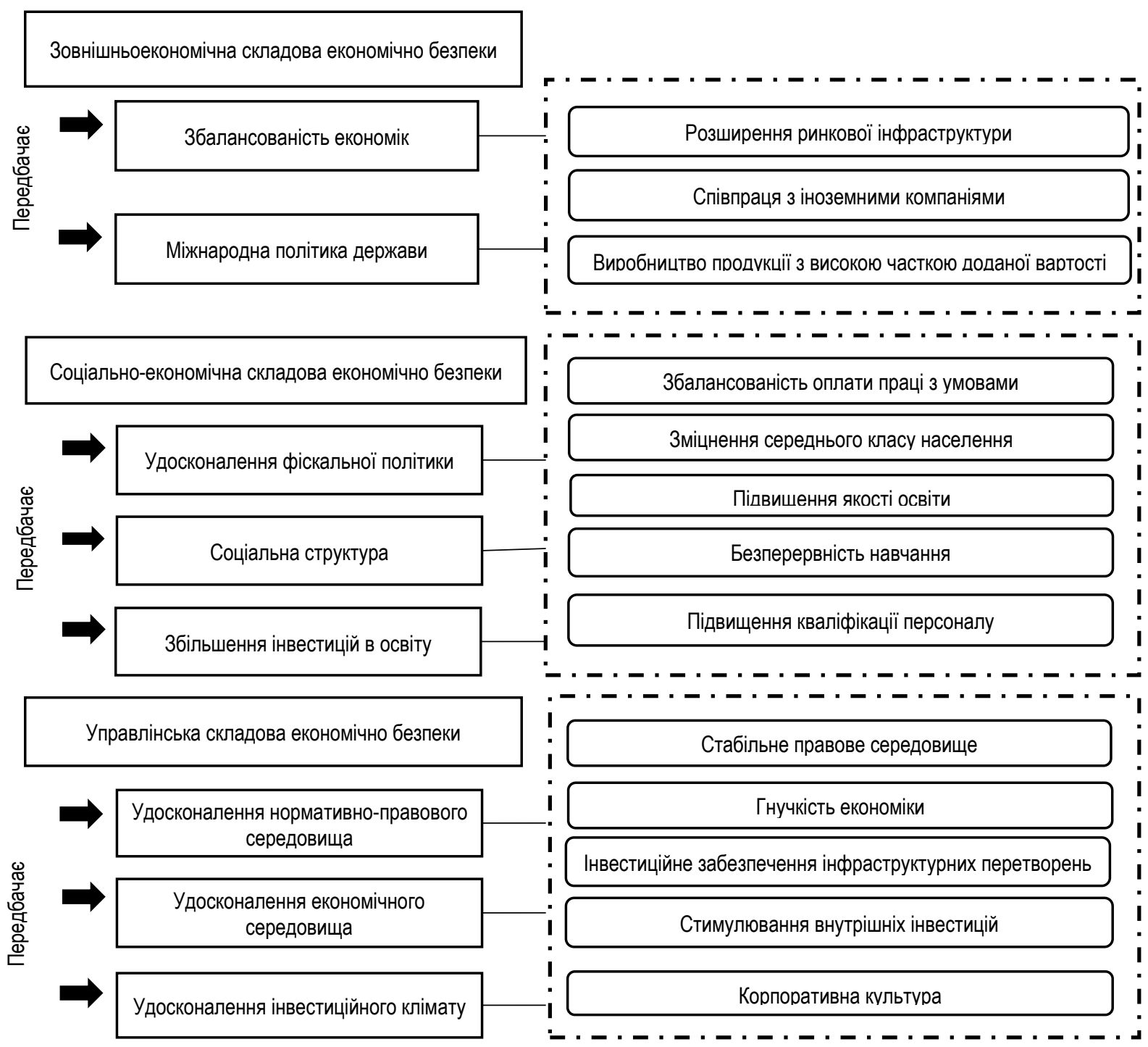

Рис. 1. Основні складові забезпечення економічної безпеки аграрного сектору економіки

Екологічна складова, яка відповідає за охорону екологічної безпеки суспільства від суб'єктів господарювання, що здійснюють виробничо-комерційну діяльність, діяльність забезпечується через розробку і ретельне дотримання національних (міжнародних) норм мінімально допустимого вмісту шкідливих речовин, які потрапляють у навколишнє середовище, а також дотримання екологічних параметрів продукції, що виготовляється.

Силова складова, яка характеризується створенням безпечних умов господарювання та розвитку аграрного сектору шляхом створення принципової схеми організації силової складової економічної безпеки 3 виокремленням послідовно виконуваних робіт.

Оскільки економічний безпека і розвиток галузі суттєво залежать від зовнішнього середовища, а саме від тенденцій розвитку світового господарства, політичної та економічної ситуації в світі та країні, доцільним є аналіз та дослідженні зовнішньоекономічної компоненти забезпечення економічної безпеки аграрного сектору.

Під зовнішньоекономічною безпекою аграрної галузі пропонуємо розуміти забезпечення мінімізації збитків галузі від дії негативних зовнішніх економічних чинників та створення сприятливих умов розвитку завдяки активній участі агроформувань у світовому розподілі праці. 3 метою оцінювання внутрішніх і зовнішніх загроз галузі доцільним є проведення моніторингів діяльності зовнішньоекономічних ринків, що дозволить суб'єктам господарювання прогнозувати можливість реалізації економічних інтересів на світовому та внутрішньому ринках. Однією з найважливіших форм прояву економічної безпеки агропромислового сектору є продовольча безпека.

Фактори ризику, небезпеки і загрози економічній безпеці агропромислового комплексу можуть бути згруповані за різними класифікаційними ознаками. Так, у залежності від можливості їх прогнозування слід виділити ті небезпеки або загрози, які можна передбачити і непередбачені. До перших 
належать ті, які виникають в певних умовах, відомі з досвіду господарської діяльності, своєчасно виявлені і розглянуті економічною наукою. Небезпеки і загрози економічній безпеці залежно від джерела виникнення ділять на об'єктивні і суб'єктивні. Об'єктивні виникають без участі і мимо волі суб'єктів господарювання, незалежні від прийнятих рішень, дій менеджера. Це стан фінансової кон'юнктури, наукові відкриття, форс мажорні обставини тощо. Їх необхідно розпізнавати і обов'язково враховувати в управлінських рішеннях. Суб'єктивні загрози які мають навмисний або ненавмисний характер, які зумовлені дією людей, різних органів і організацій, у тому числі державних і міжнародних підприємств конкурентів. Тому їх запобігання пов'язане з впливом на суб'єктів економічних відносин. Залежно від можливості зменшення або уникнення виділяють фрактори форс-мажорні і не форсмажорні. Форс-мажорні відрізняються непереборністю впливу (війни, катастрофи, надзвичайні лиха, які змушують вирішувати і діяти всупереч наміру). Другі можливо уникнути своєчасними і правильними діями. За можливістю настання всі деструктивні чинники (поява зони ризику, виклик, небезпека, загроза) можна розділити на явні, які реально існуючі, видимі. Поряд з тим існують латентні, тобто приховані, ретельно замасковані, які важко виявляються. Вони можуть проявитися раптово. Тому їх прояв потребує вживання термінових заходів, додаткових зусиль і коштів. Небезпеки і загрози можуть класифікуватися і по об'єкту посягання: персонал, майно, техніка, інформація, технологія тощо.

За природою виникнення ризики можна поділити на: політичні, економічні, техногенні, правові, кримінальні, екологічні, конкурентні, контрагентські тощо. Залежно від величини втрат або причиненої шкоди, до якого може призвести дія деструктивних факторів, небезпеки і загрози можна підрозділити на ті, що викликають труднощі, значні і катастрофрічні. За ступенем ймовірності ризики поділяються на неймовірні, малоймовірні, ймовірні, вельми ймовірні, цілком ймовірні. Найбільшого поширення у науковій літературі набуло виділення небезпек і загроз залежно від сфери їх виникнення. За цією ознакою розрізняють внутрішні і зовнішні фактори ризику. Зовнішні небезпеки і загрози виникають за межами суб'єктів господарювання. Вони не пов'язані з його виробничою діяльністю. Як правило, це така зміна навколишнього середовища, яке може нанести збиток. Внутрішні фактори пов'язані з господарською діяльністю суб'єкта, його персоналу. Вони обумовлені тими процесами, які виникають в ході виробництва та реалізації продукції і можуть зробити свій вплив на результати бізнесу. Найбільш значущими є: якість планування та прийняття рішення, дотримання технології, організація праці та робота з персоналом, фінансова політика держави, корпоративна культура та інші.. Як внутрішніх, так і зовнішніх факторів ризику величезна кількість, та всі х не можливо врахувати при здійсненні діяльності. Це зумовлено більш за все різноманітністю зв'язків і відносин, в які обов'язково вступає суб'єкт господарювання. У ході фінансових, інформаційних, кадрових та інших зв'язків відбуваються обмін, споживання та переміщення сировини, матеріалів, комплектуючих виробів, машин, обладнання, інвестицій, технологій, грошових коштів тощо. Усі ці зв'язки і відносини виникають здебільшого у конкретних політичних, соціальноекономічних, природно-кліматичних та інших умовах, які склалися як в масштабах всієї країни, так і на рівні певного конкретного регіону. Саме тому конкретна ситуація в тому чи іншому випадку в залежності від складової забезпечення економічної безпеки аграрного сектору, може зробити істотний вплив на результати господарської діяльності всього сектору.

До факторів, що впливають на результати господарської діяльності аграрного сектору, можуть бути віднесені: стан бізнес середовища, наявність місцевих сировинних і енергетичних ресурсів, розвиток транспортних та інших комунікацій, наповнюваність ринку, стан конкурентних позицій, наявність кваліфікованих трудових ресурсів, рівень їхньої професійної підготовленості, рівень соціальної та політичної напруженості в країні, орієнтування населення на продуктивну працю, рівень життя населення, його платоспроможність, тінізація економічної складової господарської життя (корумпованість чиновників, рекет, економічна злочинність) і багато інших. Усі зовнішні чинники, що впливають на економічну безпеку аграрного сектору, можна згрупувати, виділивши: політичні, соціально-економічні, екологічні, науково-технічні та технологічні, юридичні, природно-кліматичні, демограсрічні, криміналістичні та інші $[4,9]$. Під впливом зовнішнього середовища може виникнути багато небезпек і загроз економічній безпеці аграрного сектору. До них можна віднести: макроекономічні фактори (кризи, порушення виробничих зв'язків, інфляція, втрата ринків сировини, матеріалів, енергоносіїв, товарів тощо); несприятливу зміну політичної ситуації; зміна нормативно-правового забезпечення, що впливає на умови функціонування та розвитку аграрного сектору (податкового, відносин власності, договірного та ін.); нерозвиненість інфраструктури ринку; протиправні дії кримінальних структур та багато інших.

До основних чинників негативної дії можна віднести сукупність умов і фракторів, а також збіг обставин, що значно збільшують ризики життєдіяльності суб'єкта. Загрози обмежують або унеможливлюють реалізацію економічних інтересів, перешкоджають досягненню цілей підприємства, порушують його стійкий розвиток, призводять до припинення господарської діяльності.

Для формування ефективної політики щодо забезпечення економічної безпеки аграрного сектору необхідним $\epsilon$ виявлення та чітке окреслення основних її загроз та побудови їх системної класифікації. Необхідно надати максимально розгорнуту їх характеристику з метою визначення основних напрямів для протидії. Необхідно враховувати як реальні, так і потенційні загрози, оскільки останні можливо попередити. Потенційні загрози є предметом вивчення попереднього аналізу та контролю, до головних рис якого належить превентивний вплив на об'єкт. Реальні загрози, які в свою чергу, перебувають у компетенції поточного та наступного видів контролю. Різноманіття процесів, які виникають під час господарської діяльності, окреслює широкий спектр загроз, що впливають на ефективність функціонування аграрного сектору.

Слід зазначити, що багато науковців значну увагу приділяють поділу та класифікації загроз [5, 17-18.]. Однак, недоліком даних підходів $€$ неврахування ознак, що характеризують всі форми прояву загроз. Тому доцільним є розробка багатокритеріальної класифікації загроз економічної безпеки аграрного сектору (рис. 2). 


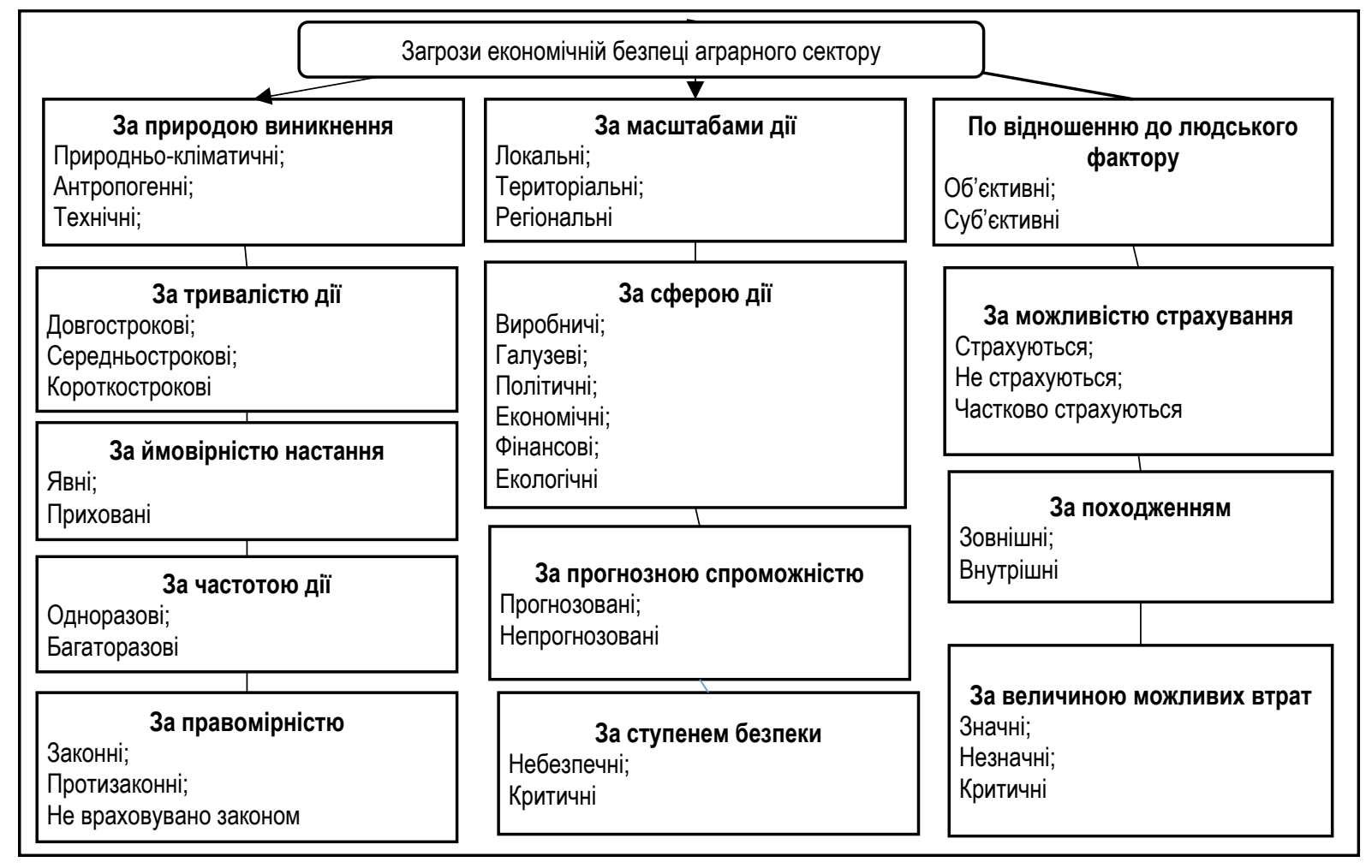

Рис. 2. Загрози економічній безпеці аграрного сектору економіки

Пропонується виділяти класифікаційні ознаки загроз економічній безпеці аграрного сектору із врахуванням галузевих особливостей, зокрема: походження загроз, сфера життєдіяльності виробника та масштаб дії, природа їх виникнення, частота дії, тривалість впливу, ймовірність настання, правомірність, можливість їх прогнозування та страхування, величина втрат, об'єкт посягань, ступінь небезпеки виробника та рівень завершеності загрозБільшість загроз взаємопов'язані та, з одного боку, обумовлюють одна одну, а, з іншого - є автономними відносно одна одної. За сферою дії загрози економічній безпеці можна поділити на виробничі (нестача ресурсів, техніки на сільськогосподарському підприємстві, знос матеріально- технічної бази, порушення технологічного процесу), галузеві (низький рівень інвестиційної при- вабливості галузі, посилення конкуренції), політичні (недосконале державне управління, зростання податкового навантаження), фінансові та економічні (нестабільність фінансовокредитних відносин, несприятлива кон'юнктура ринку, неефективний менеджмент), екологічні (небезпека від довкілля та людини), правові (нестабільність чинного законодавства).

Висновки: Таким чином, проведене дослідження щодо класифрікації загроз економічній безпеці аграрного сектору економіки, дозволило дійти висновку щодо різноманітності факторів та видів загроз економічній безпеці агарного сектору. Для зменшення негативного впливу на економічну безпеку аграрного сектору економіки доцільним є розробка низькі заходів щодо мінімізації такого впливу на державному ріBHi.

\section{Список літератури:}

1. Барановський О. І., Герасименко Л. В., Користін О. Є. Економічна безпека: навч. посіб. / за заг. ред. О. М. Джужі. Київ: Алерта; КНТ; Центр учбової літератури, 2010. 368 с.

2. Власюк О. С. Теорія і практика економічної безпеки в системі науки про економіку: наук. доповідь. Київ: Вид-во НІПМБ, 2008. 48 C.

3. Гнилицька Л. Теоретико-методологічний інструментарій формування системи забезпечення економічної безпеки підприємства. Бухгалтерський облік і аудит. 2013. № 9. С. 37-45.

4. Гришова І. Ю, Федоркін Д. В. Концептуальний підхід щодо державного управління екологічною безпекою аграрного виробництва. Наукові записки Iнституту законодавства Верховної Ради України. 2017. № 6. C. 161-167. URL: https://instzak.com/index.php/journal/article/view/53.

5. Гришова І. Ю., Гнатьєва Т. М. Управління ризиками у контексті стратегії антикризового управління. Український журнал прикладної економіки. 2016. Т. 1. № 3. С. 32-40.

6. Дубина М. В. Сутність транскордонної безпеки та передумови налагодження взаємодії прилеглих регіонів сусідніх держав. Методологічне забезпечення транскордонної безпеки України в рамках політики Східного партнерства ЄС: монографія / за наук. ред. О. І. Гонти. Чернігів: 2015. С. 6-25.

7. Дубина М. В. Сутність та компонентний склад транскордонної економічної безпеки. Вісник Запорізького національного університету: збірник наукових праць. Економічні науки. 2014. № 3. С. 174-184.

8. Економіка України: підсумки перетворень та перспективи зростання / за заг. ред. В. М. Гейця. Харків: Форт, 2000.

Вісник Сумського національного аграрного університету

Серія «Економіка і менеджмент», випуск 1 (79), 2019 
$336 \mathrm{c}$.

9. Жаліло Я. А. Економічна стратегія держави: теорія, методологія, практика. Київ: НІСД. 2003. 224 с.

10. Козаченко Г. В. Система економічної безпеки: держава, регіон, підприємство: монографія. Луганськ: Еталон, 2010. $282 \mathrm{c}$.

11. Крамарева О. М. Економічна безпека країни в умовах глобалізації. Економічна безпека держави: стан, проблеми, напрями зміцнення: матеріали наук.-практ. конф. (Харків, 10 жовтня 2008 р.). Харків: ХНУВС, 2007. С. 45-49.

12. Михасюк І. Економічна безпека країни в умовах глобалізації. Львів: Видавничий центр ЛНУ ім. Івана Франка, 2001.

$42 \mathrm{c}$.

13. Основы экономической безопасности: государство, регион, предприятие, личность / под ред. Е. А. Олейникова. Москва: ЗАО «Бизнес-школа «Интел-Синтез», 1997. 288 с.

14. Сидоренко-Стеценко С. Д. Сутність проблеми економічної безпеки України та методи її моделювання. Вісник Черкаського університету. 2009. № 152. С. 109-114.

15. Тамбовцев В. Л. Экономическая безопасность хозяйственных систем: структура проблемы. Вестник Московского университета. Сер. 6. Экономика. 1995. № 3. С. 3-9.

16. Шкарлет С. М. Економічна безпека підприємства: інноваційний аспект: монографія. Київ: Книжкове видавництво HAY, 2007. 436 c.

17. Gryshova I. Ju., Yanchuk A. O., Shestakovska T. L. The mechanism for implementing the functions of consumerism in market conditions. Scientific bulletin of Polissia. 2016. № 1 (9). Part 1. P. 93-101.

18. Hnatieva T. M., Kravchuk A. A., Hnatieva T. M. Model of economic development enterprise in the contex to European integration. Scientific bulletin of Polissia. 2017. № 3 (11). Part 2. P. 89-94.

\section{References:}

1. Baranovskyi, O. I., Herasymenko, L. V., Korystin, O. Ye., Dzhuzha, O. M. (2010). Ekonomichna bezpeka [Economic Security]. Kyiv: Alerta; KNT; Tsentr uchbovoi literatury [in Ukrainian].

2. Vlasiuk, O. S. (2008). Teoriia i praktyka ekonomichnoi bezpeky v systemi nauky pro ekonomiku: nauk. dopovid [Theory and Practice of Economic Security in the System of Science of Economics: Sciences. Report]. Kyiv: Vyd-vo NIPMB [in Ukrainian].

3. Hnylytska, L. (2013). Teoretyko-metodolohichnyi instrumentarii formuvannia systemy zabezpechennia ekonomichnoi bezpeky pidpryiemstva [Theoretical and Methodological Tools for Creating a System for Ensuring Economic Security of the Enterprise]. Bukhhalterskyi oblik i audyt - Accounting and auditing, 9, $37-45$ [in Ukrainian].

4. Hryshova, I. Yu, Fedorkin, D. V. (2017). Kontseptualnyi pidkhid shchodo derzhavnoho upravlinnia ekolohichnoiu bezpekoiu ahrarnoho vyrobnytstva [Conceptual Approach to State Management of Ecological Safety of Agrarian Production]. Naukovi zapysky Instytutu zakonodavstva Verkhovnoi Rady Ukrainy - Scientific notes of the Institute of Legislation of the Verkhovna Rada of Ukraine, 6, 161-167. Retrieved from https://instzak.com/index.php/journal/article/view/53.

5. Hryshova, I. Yu., Hnatieva, T. M. (2016). Upravlinnia ryzykamy u konteksti stratehii antykryzovoho upravlinnia [Risk Management in the Context of the Anti-Crisis Management Strategy]. Ukrainskyi zhurnal prykladnoi ekonomiky - Ukrainian Journal of Applied Economics, 1 (3), $32-40$ [in Ukrainian].

6. Dubyna, M. V. (2015). Сутність транскордонної безпеки та передумови налагодження взаємодії прилеглих регіонів сусідніх держав [Essence of Cross-Border Security and Preconditions for Establishing Cooperation between Neighboring Regions of Countries-Neighbours]. In O. I. Honta (Ed.), Metodolohichne zabezpechennia transkordonnoi bezpeky Ukrainy v ramkakh polityky Skhidnoho partnerstva YeS - Methodological Support for Ukraine's Cross-Border security within the Framework of the EU Eastern Partnership Policy (pp. 6-25). Chernihiv [in Ukrainian].

7. Dubyna, M. V. (2014). Sutnist ta komponentnyi sklad transkordonnoi ekonomichnoi bezpeky [Essence and Composition of Cross-Border Economic Security]. Visnyk Zaporizkoho natsionalnoho universytetu. Ekonomichni nauky - Visnyk of Zaporizhzhya National University. Economical Sciences, 3, 174-184 [in Ukrainian].

8. Heiiets, V. M. (Ed.) (2000). Ekonomika Ukrainy: pidsumky peretvoren ta perspektyvy zrostannia [Economy of Ukraine: Results of Transformations and Prospects for Growth]. Kharkiv: Fort [in Ukrainian].

9. Zhalilo, Ya. A. (2003). Ekonomichna stratehiia derzhavy: teoriia, metodolohiia, praktyka [Economic Strategy of the State: Theory, Methodology, Practice]. Kyiv: NISD [in Ukrainian].

10. Kozachenko, H. V. (2010). Systema ekonomichnoi bezpeky: derzhava, rehion, pidpryiemstvo [System of Economic Security: State, Region, Enterprise]. Luhansk: Etalon [in Ukrainian].

11. Kramareva, O. M. (2007). Ekonomichna bezpeka krainy v umovakh hlobalizatsii [Economic Security of the Country in Conditions of Globalization]. Proceeding from Ekonomichna bezpeka derzhavy: stan, problemy, napriamy zmitsnennia: materialy nauk.-prakt. konf. - Economic Security of the State: State, Problems, Directions of Strengthening: Materials of Sciences-Practical Conference. (Kharkiv, October 10, 2008) (pp. 45-49). Kharkiv: KhNUVS [in Ukrainian].

12. Mykhasiuk, I. (2001). Ekonomichna bezpeka krainy v umovakh hlobalizatsii [Economic Security of the Country in Conditions of Globalization]. Lviv: Vydavnychyi tsentr LNU im. Ivana Franka [in Ukrainian].

13. Oleinikov, E. A. (1997). Osnovy ekonomicheskoi bezopasnosti: gosudarstvo, region, predpriiatie, lychnost [Fundamentals of Economic Security: State, Region, Enterprise, Person]. Moscow: ZAO «Biznes-shkola «Intel-Sintez» [in Russian].

14. Sydorenko-Stetsenko, S. D. (2009). Sutnist problemy ekonomichnoi bezpeky Ukrainy ta metody yii modeliuvannia [Essence of the Problem of Economic Security of Ukraine and Methods of its Modeling]. Visnyk Cherkaskoho universytetu - Bulletin of Cherkasy University, 152, 109-114 [in Ukrainian]. 
15. Tambovtsev, V. L. (1995). Ekonomicheskaia bezopasnost khoziaistvennykh sistem: struktura problemy [Economic Security of Economic Systems: the Structure of the Problem]. Vestnik Moskovskogo universiteta. Ser. 6. Ekonomika - Bulletin of Moscow University. Ser. 6. Economy, 3, 3-9 [in Russian].

16. Shkarlet, S. M. (2007). Ekonomichna bezpeka pidpryiemstva: innovatsiinyi aspekt [Economic Security of an Enterprise: an Innovative Aspect]. Kyiv: Knyzhkove vydavnytstvo NAU [in Ukrainian].

17. Gryshova, I. Ju., Yanchuk, A. O., Shestakovska, T. L. (2016). Mechanism for Implementing Functions of Consumerism in Market Conditions. Scientific bulletin of Polissia, 1 (9). Part 1, 93-101 [in English].

18. Hnatieva, T. M., Kravchuk, A. A., Hnatieva, T. M. (2017). Model of Economic Development of the Enterprise in the Contex to European integration. Scientific bulletin of Polissia, 3 (11), Part 2, 89-94 [in English].

Kushnir Svetlana, PhD, Associate Professor, Zaporizhzhya National University (Zaporozhye, Ukraine)

Characteristics of and risks factors institutional economic security of the agricultural sector

The article deals with the main factors of negative action and risks of institutional economic security of the agricultural sector, which include a set of conditions and factors, as well as a set of circumstances that significantly increase the risks of life of the business entity. To form an effective policy to ensure the economic security of the agricultural sector is necessary to identify and clearly define its main threats and build their systematic classification is Proposed to identify the classification features of threats to the economic security of the agricultural sector, taking into account industry characteristics, developed a multi-criteria classification of threats to the economic security of the agricultural sector.

Key words: security, national security, economic safety, scientific approach, economic security of the agrarian sector.

Дата надходження до редакції: 17.10.2018 р. 